\title{
Conscience's De Leeuw van Vlaanderen (The Lion of Flanders) and Its Adaptation to Film by Claus
}

\author{
Gertjan Willems \\ Ghent University
}

Follow this and additional works at: https://docs.lib.purdue.edu/clcweb

Part of the Comparative Literature Commons, Dutch Studies Commons, European Languages and Societies Commons, Film and Media Studies Commons, Social and Behavioral Sciences Commons, and the Television Commons

Dedicated to the dissemination of scholarly and professional information, Purdue University Press selects, develops, and distributes quality resources in several key subject areas for which its parent university is famous, including business, technology, health, veterinary medicine, and other selected disciplines in the humanities and sciences.

CLCWeb: Comparative Literature and Culture, the peer-reviewed, full-text, and open-access learned journal in the humanities and social sciences, publishes new scholarship following tenets of the discipline of comparative literature and the field of cultural studies designated as "comparative cultural studies." Publications in the journal are indexed in the Annual Bibliography of English Language and Literature (Chadwyck-Healey), the Arts and Humanities Citation Index (Thomson Reuters ISI), the Humanities Index (Wilson), Humanities International Complete (EBSCO), the International Bibliography of the Modern Language Association of America, and Scopus (Elsevier). The journal is affiliated with the Purdue University Press monograph series of Books in Comparative Cultural Studies. Contact: <clcweb@purdue.edu>

\section{Recommended Citation}

Willems, Gertjan. "Conscience's De Leeuw van Vlaanderen (The Lion of Flanders) and Its Adaptation to Film by Claus." CLCWeb: Comparative Literature and Culture 16.3 (2014): <https://doi.org/10.7771/1481-4374.2318>

This text has been double-blind peer reviewed by $2+1$ experts in the field.

The above text, published by Purdue University Press @Purdue University, has been downloaded 365 times as of $11 /$ $07 / 19$.

This document has been made available through Purdue e-Pubs, a service of the Purdue University Libraries. Please contact epubs@purdue.edu for additional information.

This is an Open Access journal. This means that it uses a funding model that does not charge readers or their institutions for access. Readers may freely read, download, copy, distribute, print, search, or link to the full texts of articles. This journal is covered under the CC BY-NC-ND license. 


\section{PURDUE}

U N I V E R R S I T Y Y UNIVERSITY PRESS < http://www.thepress.purdue.edu>

\section{CLCWeb: Comparative Literature and Culture}

ISSN 1481-4374 <http://docs.lib.purdue.edu/clcweb> Purdue University Press @Purdue University

CLCWeb: Comparative Literature and Culture, the peer-reviewed, full-text, and open-access learned journal in the humanities and social sciences, publishes new scholarship following tenets of the discipline of comparative literature and the field of cultural studies designated as "comparative cultural studies." In addition to the publication of articles, the journal publishes review articles of scholarly books and publishes research material in its Library Series. Publications in the journal are indexed in the Annual Bibliography of English Language and Literature (Chadwyck-Healey), the Arts and Humanities Citation Index (Thomson Reuters ISI), the Humanities Index (Wilson), Humanities International Complete (EBSCO), the International Bibliography of the Modern Language Association of America, and Scopus (Elsevier). The journal is affiliated with the Purdue University Press monograph series of Books in Comparative Cultural Studies. Contact: <clcweb@purdue.edu>

\section{Volume 16 Issue 3 (September 2014) Article 7 Gertjan Willems, "Conscience's De Leeuw van Vlaanderen (The Lion of Flanders) and Its Adaptation to Film by Claus" \\ <http://docs.lib.purdue.edu/clcweb/vol16/iss3/7> \\ Contents of CLCWeb: Comparative Literature and Culture 16.3 (2014) \\ Including Thematic Cluster Love, Sexualities, and Marriage in Literature \\ <http://docs.lib.purdue.edu/clcweb/vol16/iss3/>}

Abstract: In his article "Conscience's De Leeuw van Vlaanderen (The Lion of Flanders) and Its Adaptation to Film by Claus" Gertjan Willems discusses Hugo Claus's 1984 filmic adaptation of Hendrik Conscience's 1838 historical novel, a landmark in the history of the Flemish Movement. Willems's analysis is executed by means of a textual film analysis and archival research. Willems pays special attention to the Flemish-Dutch coproduction's complex relations with the national question. Despite various difficulties concerning Flemish nationalist sensitivities of the project, the producers wanted the film to be as faithful as possible to Conscience's novel. This resulted in an overtly romantic and Flemish nationalist production despite some counterpoints introduced by the controversial and critical director Claus. Although De Leeuw van Vlaanderen was the most expensive production in Belgium's film history, it turned out to be an unprecedented critical and commercial failure. 


\section{Gertjan WILLEMS}

\section{Conscience's De Leeuw van Vlaanderen (The Lion of Flanders) and Its Adaptation to Film by Claus}

To commemorate the one hundredth anniversary of the death of Hendrik Conscience, a key figure in the history of the Flemish Movement, a series of exhibitions, publications, theatrical performances, and other ceremonies was set up in 1983. In this context, the filmic adaptation of Conscience's 1838 novel De Leeuw van Vlaanderen of de Slag der Gulden Sporen (The Lion of Flanders or the Battle of the Spurs) by Hugo Claus was conceived as a spectacular medieval epic that would serve as a concluding memorial showpiece. Offering a romanticized account of the Flemish victory over the French during the 1302 Battle of the Spurs, Conscience's novel is presumably the most important literary work of the Flemish Movement's symbolic and mythological repertory throughout the nineteenth and twentieth centuries. The 1984 film and later television series in 1985 - both directed by Claus and titled De Leeuw van Vlaanderen - was a coproduction between Kunst en Kino, the Flemish public broadcaster BRT (Belgische Radio- en Televisieomroep), the Ministry of the Flemish Community, and the Dutch public broadcaster KRO (Katholieke Radio Omroep). The total cost of the production of the film was approximately 80 million Belgian francs making it the most expensive film product in the Low Countries at the time. Its budget notwithstanding, the film did not succeed in finding a large audience and instead became one of the most heavily criticized flops in Flemish film and television history. During the period of difficulties in Belgian society and politics in general and Flemish emancipation in particular, a large part of the controversy surrounding the production was caused by Flemish nationalist associations. Of note is that in scholarship this kind of film dealing with a "glorious" past is discussed often in a context of nationalist perception (see, e.g., Chapman; Higson; Naremore).

In the study at hand, I examine how the film and its production and reception are located in the context of Flemish nationalism and I pay attention to power relations between various agents and how they tried to impose their views on the project. My source material includes archival data from the Flemish government's film department records "Archives of Media and Film 2004" in the State Archives in Beveren (hereafter SAB) and the records of the Flemish public broadcaster in Brussels (Documents Archives of the Dossiers of the Institute's Secretary, hereafter DAVRT). For the analysis 92 newspaper and magazine articles were collected from the Royal Film Archive (Brussels), the Documentation Centre for the Cinematographic Press (Brussels), and the records of Cinema Zuid (Antwerp). I also relate my discussion to the largely unwritten history of recent cultural nationalism in Flanders and Belgium.

In a similar epic way as the then popular historical novels of Walter Scott, Conscience (1812-1883) published De Leeuw van Vlaanderen, a novel about the so-called Battle of the Spurs in 1302. The historical events of 1302 concerned a complex feudal conflict between the Count of Flanders and the King of France. Various political and social interests were involved, but national motives were non-existent at the time (see Lambert). Despite Conscience's research in preparation for the writing of the novel, he did not want to write a historically accurate novel (see, e.g., Wauters). Instead, Conscience - as supporter of the early Flemish Movement which strove for the linguistic and cultural recognition of Flanders, the northern, Dutch-speaking region within Belgium - intended to tell a romantic story for the purpose of creating a sense of Flemish awareness and nationhood (see Wauters). At the same time, Conscience's novel can be understood only in the Belgian national context. Indeed, the then emerging Flemish Movement in general and Conscience's Flemish emancipatory spirit in particular did not contrast with Belgian patriotism.

In the nineteenth and early twentieth century De Leeuw van Vlaanderen became a popular success and a cultural landmark for the Flemish. In this context, the novel was also largely responsible for creating a cult around the Battle of the Spurs. Parallel to the novel's growing fame, both the novel and its cult were placed more and more within an exclusively Flemish symbolic framework (see Tollebeek). With the Belgian state reforms during the second half of the twentieth century, the social, cultural, political, and institutional conditions of Flanders changed dramatically. As the unitary Belgian state turned into a federal state, Flanders acquired more autonomy on various levels (see Witte). This advancing Flemish emancipation caused a decline in the need for heroic stories about the Flemish people 
and their past (see Beyen). De Leeuw van Vlaanderen, however, kept its place within collective memory as it had become a firmly fixed mythological point of reference and the Battle of the Spurs had become one of the strongest lieux de mémoire of Flanders (for the concept of lieux de mémoire see Nora). At the same time, fewer people read the novel and the (literary) appreciation for Conscience was also decreasing. In certain circles, this caused a striving for Conscience's rehabilitation, which came to a climax in 1983 with Claus's adaptation of the novel to film. A series of exhibitions, publications, theatrical performances, and other ceremonies were set up in honor of Conscience. In addition to the film, a television series De Leeuw van Vlaanderen was produced and directed by Claus. The development of both film and television series took place between 1977 and 1984 against the backdrop of a turbulent and crucial socio-political period for the Flemish Movement. The widely supported protests against the state reform plans of the so-called Egmont Pact not only caused a government crisis, but instigated the secession of a radical right wing from the pro-Flemish party the Volksunie. Moreover, after state reform in 1980 - which divided Belgium into communities and regions with their own governments - the developments within the Flemish Movement and the various community difficulties created tensions within Belgian society. This made the filmic and television adaptation of Conscience's novel the pre-eminent "Flemish nationalist bible," a sensitive project.

Around 1977, Jean or Jan Van Raemdonck asked Claus to write a screenplay for a television series based on Conscience's De Leeuw van Vlaanderen. As the CEO of Kunst en Kino, at the time one of the biggest production companies in Belgium, Van Raemdonck wanted to make a spectacle production about knights, castles, and battles in Flanders. Apart from the lack of tradition and experience in this genre, there was also the problem of the small home market that made fund-raising for Belgian films difficult. Van Raemdonck, however, hoped that the upcoming Conscience year of 1983 would enable him to find the necessary funding for his project. The final budget of the production was approximately 80 million Belgian francs, almost four times the average budget of a Flemish film, but still only a fifth of the average Hollywood film at the time.

The first partner who joined Kunst en Kino was the Flemish public broadcaster BRT. Along with a few minor sponsors, the Dutch public broadcaster KRO was also contacted to coproduce De Leeuw van Vlaanderen. In October 1980, Van Raemdonck applied for funding by the Department of Film of the Ministry of the Flemish Community. The Ministry's film Commission, however, judged the project negatively. Among other arguments, the Commission found that it would not be appropriate that half of the yearly film budget would be devoted to a single project. The then State Secretary for Culture Rika De Backer, from the Christian Democratic political party (CVP) - however, decided to ignore the Commission's advice and granted the project 25 million Belgian francs. Such a deviation from the Commission's advice was unusual and the Commission expressed its discontent in a special note to the new Minister of Culture, Karel Poma (from the Liberal party [PVV]), who replaced De Backer at the end of 1981. The Commission argued that both the experience and the means to produce such a historical spectacle in film were lacking in the Low Countries. Moreover, they stated that "nowadays, the heroic historiography as practiced in The Lion of Flanders, is no longer justified and makes a mockery of the historical truth" (RAB nr. 19, Note to Poma, 28 January 1982; unless indicated otherwise, all translations are mine). Neither De Backer nor Poma responded to the Commission's objection to a romantic representation of history à la Conscience. Later, the press would criticize De Leeuw van Vlaanderen exactly on the basis of these two arguments: the insufficient means and knowhow and the romantic nationalist character of the film.

Notwithstanding the Commission's protests, Kunst en Kino, the BRT, the KRO, and the Flemish Ministry of Culture signed the production agreement on 17 March 1982. Within the politically appointed board of directors of the BRT, however, there was also no consensus about the desirability of De Leeuw van Vlaanderen. The CVP representatives were largely in support of the production, but it was primarily the Administrator General of the BRT, Paul Vandenbussche (also associated with the CVP), who proved to be the project's greatest supporter. This support may seem somewhat surprising, as the popularity of historical television fiction was losing ground to more contemporary fiction. Nevertheless, the BRT invested even more in historical fiction during the 1980 s than before. Alexander Dhoest explains this contradiction by referring to the prominence of Flemish nation-building of the time and the fact that Flanders wanted to position itself strongly on the cultural level. This should be seen within the broader role of the Flemish public broadcaster in turn within the construction of a 
Flemish identity (see Van den Bulck). In this context, the BRT had the tradition of paying attention to glorious figures or periods from Flemish history. This reasoning was reflected in the arguments of the CVP representative Johan Fleerackers, who wanted to resist the cultural "eroding" of the BRT and therefore considered the adaptation of Conscience's national epic as a crucial element in the identity construction of the BRT (DAVRT, Letter from Fleerackers to Balthazar 12 May 1982).

It was mainly the Liberal representatives Adriaan Verhulst (a prominent supporter of the Flemish Movement) and Armand Beyens together with the representative of the pro-Flemish Volksunie Antoon Van Overstraeten, who opposed the project. They argued that the project was financially too risky and that there were other, more contemporary, subjects "than De Leeuw van Vlaanderen to propagate our cultural heritage" (DAVRT nr. 32, 3 May 1982). The most pro-Flemish board members thus opposed an adaptation of the most important literary work of the Flemish Movement. Besides financial and production related motives, the reason for this apparent contradiction can be explained by the evolution of Flemish nationalist ideology which distanced itself more and more from the romantic and mythologizing aspects it emphasized in the past. In turn, this can be linked to broader developments concerning the deconstruction of national myths. As a historian, Verhulst indeed criticized regularly the lack of historical accuracy in the screenplay. Other board members, however, argued that it had never been the aim to present a historical representation of the events: "The aim is an adaptation of a subject that Conscience has made into a national epic" (DAVRT nr. 32, 3 May 1982). This points to the fact that the supporters of the adaptation were clearly aware of the romantic nationalist character of the project. At the same time, the emphasis on Conscience's novel rather than on the historical events of 1302 can also be seen as a strategy to depoliticize the representation. The argumentation could have been that when the film is treated as fiction, there are no ideological motivations involved concerning the specific representation of the past. This reasoning, however, did not take into consideration that fiction can also be interpreted in political and ideological terms, particularly when a filmic adaptation of Conscience's novel is concerned. After months of heated discussions, several opponents of the project were convinced when a "more modest version" of the novel with a smaller participation by the BRT was proposed (DAVRT nr. 33, 17 May 1982). On 7 June 1982, the majority of the BRT's board of directors voted in favor of the realization of De Leeuw van Vlaanderen.

One of the sensitivities in the production process was the appointment of Claus as the film's director. The KRO had suggested Claus, the most prominent postwar literary figure in Flanders, because he was the only Flemish director who was also a public figure in The Netherlands. Various people within the BRT, however, were not amused with the choice. This was particularly true for the most proFlemish members of the board of directors, Verhulst and Van Overstraeten. The controversy around the choice of Claus was motivated by his reputation: ever since his debut novel in 1950, Claus had revealed himself as the enfant terrible within the Flemish cultural and broader public (see Absillis). Although Claus always had an ambiguous relationship with Flanders, he was primarily known for his critical stance towards Flemish nationalism. Nevertheless, Claus accepted the offer to make an adaptation of De Leeuw van Vlaanderen. Claus probably had several motivations for his choice. On the one hand, he always wanted to reach the biggest possible audience, certainly with his cinematic creations (see Jacobs, Landuyt, Lembrechts, Wildemeersch) and in this respect De Leeuw van Vlaanderen set up as a Flemish blockbuster appeared promising. At the same time, Claus argued that he wanted to make a big epic, a true medieval entertainment film, and the only possibility to do this in Flanders was to adapt Conscience's novel. Moreover, Claus thought that he would be able to bend the project to his will, just like he had made a theater adaptation of parody of one of Conscience's other novels in 1966.

The producers, however, wanted a "faithful" adaptation of Conscience's novel and tried to prevent Claus from giving the adaptation a critical or ironical twist. Special offices of supervision were created through which the producers intended to maintain control over the production. A Supervision Committee was put in charge of the approval of the project plans, the surveillance over the progress of the production, and the approval of the final editing. The Committee could ask for changes in the script and the cast and also had a representative on the set. When there was a disagreement within the Committee, final decision was reserved for the Board of Commissioners (in practice, this board never had to meet). Thus, Claus was restricted in his artistic freedom. The Committee, for example, asked to restrict the use of cursing in the film and when Claus wanted to follow the historical consultant's ad- 
vice, the Committee warned him that "it is the task of the director to adapt Conscience, not to improve him" (RAB nr. 249-253, 20 May 1983).

The final product shows that the producers largely succeeded in imposing their will. The film opens with images of cows and horses, Flemish peasants working in the fields, and the slaughtering of a bullock. These and other aspects of life in the countryside presented in the film should be seen from within the context of Flemish audiovisual fiction of the 1970s and 1980s (see Willems). In both films and television productions, pastoral period dramas - based often on a literary work - took a prominent place. Dhoest shows how these productions can be seen as functional for the construction of a Flemish nation. In the film, however, the "familiar" (for a Flemish audience) peasant imagery is exchanged for the "unfamiliar" genre of the medieval spectacle film as it continues by showing a group of French noblemen. While heading to the castle of Wijnendale, the French are attacked by the brave Jan Breydel, the Flemish head of the peasants. Upon arrival at Wijnendale, the French noblemen convince the Count of Flanders, Guy of Dampierre, to ask for leniency from King Philip the Handsome. After doing so, the count and his companions are imprisoned by the French. Jacques de Châtillon is appointed as the new governor of Flanders and is ordered to kidnap Matilda of Béthune, the granddaughter of the Flemish count. While Matilda's father, Robert of Béthune, saves her, de Châtillon terrorizes Bruges. When the family of Breydel is murdered, he meets up with the head of the weavers, Pieter De Coninck to take over the city from the French (the so-called Bruges Matins). The French king wants revenge and gathers a large army for the ultimate confrontation on 11 July 1302 . With the help of Béthune, dressed in a suit of golden armor, the Flemish win the Battle of the Spurs.

Although Conscience's historical novel is of course more extensive with extra story lines, characters and elaborations, the film's narrative corresponds largely to the narrative of the novel. This implies that there are several historical inaccuracies in the film. For example, neither Breydel nor De Coninck (who was not the head of the weavers) participated in the Bruges Matins, and Béthune was imprisoned during the Battle of the Spurs. The film also takes over various anachronisms from the novel, such as the use of the term Klauwaerts, while the real name of the supporters of the Count of Flanders was Liebaerts (see de Tollenaere and de Tollenaere). Further, several scenes in the film take over the dramatic development of separate parts of the book. The use of the voice-over is remarkable because it does not provide historical explanations for the represented images and events (as is often the case with historical films), but functions to clarify the film's narrative and thus the voice-over seems to act as a personalization of Conscience's novel by quotations from the novel. Importantly, the voice-over takes the side of the Flemish: for example, the French king is described as "useless" and at the end of the film the voice-over identifies with the Flemish by talking about them in first-person plural.

The film also follows Conscience's novel by creating a dichotomy between "good Flemish" and "evil French." The first Flemish character presented in the film is Jan Breydel. As he fights the French soldiers and knights with his bare hands to liberate a Flemish peasant, he represents the heroic courage of the Flemish. At the same time, the main idea of the film is introduced: the seemingly weak Flemish succeed in liberating Flanders from the French oppressors thanks to their exceptional character traits such as honor and heroism. These characteristics, often accentuated by the use of music, culminate at the end of the film in the character of Béthune, the "Lion of Flanders." While his appearance is decisive in winning the Battle of the Spurs, the golden knight does not reveal his identity and this is a suggestion of modesty. Despite the fact that the medieval region of Flanders around 1300 was another territory than present-day Flanders, an image of "the Flemish" as an old race that survived throughout the centuries is created. It is thus suggested that the contemporary Flemish are connected directly to the brave Flemish of the story, who are being represented as a homogenous and harmonious community. When they loudly shout "Flanders the lion!" together, it becomes clear that Flemish noblemen and working class people are connected through their common patriotism and fight against French oppression.

The Flemish also share a sincere religious faith connected to their patriotism and their victory over the French. At the end of the Battle of the Spurs, a grand religious procession takes place to thank god for the Flemish triumph. Similarly, Béthune prays to god before he wins a duel against Châtillon. During the victorious speech after the Bruges Matins, church bells can be heard in the background. Just like in Conscience's novel, their love for god and Flanders reaches a common climax just before 
the Battle of the Spurs, when the Flemings kneel on the ground and, as is in the novel, "swallow each a little earth from the soil of their fatherland" (295). The bond between the Flemish and the "Flemish soil" is also emphasized through the use of costumes. Flemish working class people are always dressed in yellow, brown, and beige in harmony with the Flemish landscape. In the costumes of the French, blue is the dominant color, which contrasts with the green, brown, and yellow colors of the landscape and makes it clear that the French do not belong there. The costumes of the Flemish noblemen include various black and yellow elements, which again represent Flemish patriotism as the coat-of-arms of Flanders was a black lion on yellow background.

Opposing the brave and honorable Flemish are the decadent and cowardly French who betray the order of knighthood. Only the French king's brother, Charles of Valois, is represented as a respectable nobleman, but he disappears from the film after half an hour. The other French characters are evil and conduct a veritable reign of terror over Bruges. Their cruelty is illustrated by the killing of the innocent mother, sister, and the little brother of Breydel. The revenge of the Flemish, the Bruges Matins, is also ruthless, but just like in Conscience's novel, this violence is represented as justified. The French are represented beyond cruel, not least through the French queen Joan I of Navarre, who makes a call to kill all Flemish: "Also the women and children, for they bear in them the germ of evil. These Flemish women, they are sows whose teats are to be cut off. And these children, piglets to be roasted on the spit!" ("Ook de vrouwen en de kinderen, want daarin schuilt het zaad van het kwaad. Die Vlaamse vrouwen, dat zijn zeugen, waarvan de uier afgesneden moet worden. En die kinderen, biggen, die aan het spit geroosterd moeten worden!").

The goodness of the Flemish is emphasized by simplistic dual oppositions with the evil French. The presentation of characters in oppositional couples advances an interpretation of the historical events of 1302 as a struggle between good and evil (see Tollebeek and Verschaffel). Thus, the Count of Flanders is opposed to the French king, Béthune is opposed to Châtillon, and Matilda of Béthune is opposed to Joan I of Navarre. Although the contrast between the Flemish and the French is most striking in the representation of the characters, it is also played out on various other levels such as the previously mentioned use of costumes and mise-en-scène. Further, the camera work and the editing often function to confirm the contrast. When the French king is shown for the first time in the film, this is done by means of a low-angle shot to make him look more imposing. The following high-angle shot of the Flemish noblemen emphasizes their inferiority to the French king. However, later the power relations are reversed, which has an impact on the use of the camera. For example, the film shows a lowangle shot of Breydel and some other Flemish characters who are preparing themselves for the Battle of the Spurs. Clearly, to succeed as a mainstream film, it is almost always necessary to distort historical facts and introduce fictive elements, which from a historical point of view does not necessarily devalue the film (see Rosenstone). The reduction of the historical events of 1302 to a national opposition between "good" and "evil," however, is not only historically inaccurate, it also opposes the spirit of history, which restricts the value of the film as a historical evocation. Of course, this is connected to the film's fidelity towards Conscience's novel, to which the same historical criticism can be applied.

Some of the film's nationalistic elements, however, can be seen as exaggerated and therefore ironic (e.g., the above quotation from Navarre). In this context, the use of language in the film can be subject to various interpretations. Both the Flemish and the French speak Dutch in the film, which may be considered as a critical intervention through which the French enemy looks more like the Flemish. In practice, however, the coproduction circumstances forced the filmmakers to only cast Flemish and Dutch actors. It should be noted here that while Dutch and Flemish are one and the same language when written, they have their own distinct pronunciation. The Flemish-Dutch contradiction, just like the Flemish-French dichotomy, is a classic motive within Flemish nation-building (see Morelli), and this emphasizes the contrast between "good Flemish" and "evil French." Claus argued that this choice signified a critique of contemporary society: "I think the language of the oppressor is northernDutch. At that time, the French were dominant in Flanders. Those characters speak their own, somewhat stuck-up and haughty Dutch against the stronger Dutch from the Middle Ages that is closer to our language" ("de taal van de verdrukker vind ik het Noord-Nederlands. Op dat moment was de Fransman de dominante figuur in Vlaanderen. Die personages spreken hun eigen, bekakt, wat hautain Nederlands tegenover het wat krachtiger Nederlands uit de middeleeuwen waar wij dichterbij staan" [Claus qtd. in Temmerman 8). 
Sometimes less ambiguously critical elements can be detected in the film. True to his reputation as a provocateur, Claus mentioned in interviews that he would get rid of Conscience's piety. This happens through the representation of femininity in the film. For example, Joan I of Navarre demonstrates her sensuality, for example by taking a bath with her playful ladies-in-waiting. Or, dark-haired and sexual French women devise a plan to kidnap the blond and modest Flemish girl Matilda to re-educate her at the French court "by the most lascivious of our ladies-in-waiting." Apart from the display of sexuality, the film also shows a French noblewoman fighting with Béthune and this contrasts with Conscience's view on femininity. The Flemish women in the film, however, do not show such emancipation, which again confirms the contrast between the dangerous, decadent French and the pious Flemish. Other aspects which go against Conscience's romantic novel are the ironic elements in the film. In this respect, Claus has stated that he did not want to "hide the romantic character of the story. At sudden moments, the romantic impudently comes to the fore, but at other moments, I introduce some counterpoints, a somewhat more cynical look at the history" (Claus qtd. in Duynslaegher 62). An example of this is Breydel's clumsy appearance after the bombastic and nationalistic speech of De Coninck, in which he quotes from Conscience's novel and compares the French to caterpillars to be trampled by the Flemish peasants.

The clearest illustration of Claus's critical and ironic touch appears at the end of the film when the Flemish find the golden suit of armor of Béthune, who played a decisive role in winning the Battle of the Spurs. They honor his suit of armor as a relic and hang it on a cross of branches. A great mass of people subsequently forms a pilgrimage to the relic while the voice-over can be heard: "Then we all knelt down and sang... and proudly offered up our grateful prayers to merciful heaven, abode of the saints including our Golden Knight. May God bless him for all eternity" ("En dan hebben we geknield en gezongen, en onze gebeden vol dank en trots gezonden naar de genadige hemel, waar de heiligen wonen, waaronder onze gouden ridder. God zegene hem in de eeuwigheid"). The exaggerated devotion and the easy association of the suit of armor on the cross with an ordinary scarecrow negate the heroic character of the event. The Flemish people kneel for a dead symbol, which can be interpreted as a critique of the romanticism of Flemish nationalism. In this respect, Claus speaks about "a parodistic indication that people simply believe in everything that is presented to them as a totem" (Verschooten 4). Speaking generally, however, such critical and/or ironic elements are relatively few. Hence, the romantic and nationalistic aspects from Conscience's version are dominant, which makes the film largely in tune with the producer's vision.

Already during the production process the film received much publicity, mainly in the Flemish, but also in the Dutch and Belgian Francophone press. This was largely owing to the producers' efforts to market film as an important cultural and political event. Consequently, the film's gala première at the Brussels Film Festival on 27 January 1984 attracted much media attention. Next to various prominent political and cultural figures, the King and Queen of Belgium attended the screening. During the preparations for the première, the Queen's secretary insisted on inviting a number of Francophone people, as the show "should not become a purely Flemish affair" (RAB, nr. 249-253, 4 January 1984). I posit that such considerations should be seen within the social turmoil in Belgium at the time of the film's release. In this context, several separatist demonstrations of the radical wing of the Flemish Movement took place. At the première there were no big riots, but the extreme right-wing political party Vlaams Blok did circulate leaflets against Belgium.

Despite the political sensitivity surrounding the production of the film, the Flemish press paid little attention to the politics of nationalism before the release of the film. While the Francophone Belgian press did express their concerns about the Flemish nationalist associations of the production, the Flemish press focused on the large-scale scope of the production itself. In exceptional cases that the possibility of a Flemish nationalist production was mentioned, this argument was mostly waved aside because it was Claus who would direct the film: "if you know Hugo Claus a little bit, you know you should not expect a nationalistic epic" (Trappeniers 3 ). Such statements point to the dominance of an over-simplified auteur paradigm, which sees the director as the ultimate creator of the work and underestimates the agency of others such as those who in fact control the director of the film. And after the film's première, most of the Flemish critics wrote negative reviews of the film. Apart from its perceived dullness and incoherence, the film was criticized for its amateurism, for example in the employment of too few extras in the crowd scenes. For the Flemish journalists, the question about the 
film's relation to Flemish nationalism was again a matter of minor concern. Perhaps, Conscience's novel was so strongly embedded in collective memory that the nationalist potential of the film went almost unnoticed.

Unlike their Flemish colleagues, the negative reviews by Francophone Belgian critics were mostly based on a political-ideological interpretation of the film. Despite the fact that the film deals with the "French" played by Dutch actors, several journalists feared that the film would inspire Flemish youngsters to develop feelings of hate and violence towards the Walloon (the southern, French-speaking population of Belgium). While the Flemish press was somewhat surprised by these nationalist readings, there was also a small, but distinct Flemish nationalist faction that criticized the film for exactly the opposite reasons as the Francophone press: they denounced the lack of respect for Conscience's novel and pointed at the few ironic elements in the film to show that Flemish culture and ideology was being ridiculed. The film was thus heavily attacked from all sides. As a result, Claus soon distanced himself from his film and saw his project as a slur on his artistic career: "that film is a low point in my life" (Claus qtd. in Beyen 318).

In conclusion, the Flemish public broadcaster wanted to make a prestigious film production to commemorate Conscience and his 1838 novel De Leeuw van Vlaanderen of de Slag der Gulden Sporen, a symbol of the nineteenth-century Flemish Movement. While several funding agencies were involved in the production of the film, objections were raised by the Flemish Film Commission against an overtly nationalist film. The producers indeed wanted the film to be as faithful as possible to Conscience's novel. Despite some ironic and critical counterpoints introduced by the controversial director Claus, the 1984 film was indeed predominantly romantic and Flemish nationalist. As in Conscience's novel, the selective and historically inaccurate representation of the past served to illuminate the nationalist victory of the "good Flemish" over the "bad French." Although the film was the most expensive production in Belgium's film history at the time, it turned out to be an unprecedented critical and commercial failure.

Note: Parts of above article appeared previously in Willems, Gertjan. "'De Leeuw van Vlaanderen wil ik zo gauw mogelijk vergeten.' Over de productie en receptie van de film en televisieserie De Leeuw van Vlaanderen (1984)," Journal of Belgian History / Belgisch Tijdschrift voor Nieuwste Geschiedenis / Revue Belge d'Histoire Contemporaine 43.2-3 (2013): 178-209. Copyright release to the author.

\section{Works Cited}

Absillis, Kevin. "'Je faam is, geloof ik, definitief gevestigd': Hugo Claus' Opmerkelijke Intrede in de Vlaamse Letteren" ("'Your Fame Is, I Believe, Definitively Established': Hugo Claus's Remarkable Entry in Flemish Literature"). Het Teken van de Ram 4: Bijdragen tot de Claus-Studie. Ed. Georges Wildemeersch. Amsterdam: De Bezige Bij, 2005. 235-62.

Beyen, Marnix. Held voor Alle Werk: De Vele Gedaanten van Tijl Uilenspiegel (Hero for All Work: The Many Appearances of Tijl Uilenspiegel). Antwerpen: Houtekiet, 1998.

Chapman, James. Past and Present: National Identity and the British Historical Film. London: IB Tauris, 2005.

De Leeuw van Vlaanderen (The Lion of Flanders). Dir. Hugo Claus. 1984. Brussels: Eyeworks, 2008.

Conscience, Hendrik. De Leeuw van Vlaanderen of de Slag der Gulden Sporen (The Lion of Flanders or the Battle of the Spurs). Antwerpen: De Cort, 1838.

Conscience, Hendrik. The Lion of Flanders or the Battle of the Golden Spurs. 1838. Trans. Louis Couperus. Baltimore: John Murphy, 1912.

De Tollenaere, Felix, and Herman A.O. De Tollenaere. "Etymologica:Clauwaert, Liebaert, Leliaert" ("Etymology: Clauwaert, Liebaert, Leliaert"). Tijdschrift voor Nederlandse Taal- en Letterkunde 121.1 (2005): 74-82.

Dhoest, Alexander. "Reconstructing Flanders. The Representation of the Nation in Flemish Period Drama." Communications 28.3 (2003): 253-74.

Duynslaegher, Patrick. "Een Opera voor Vlaanderen" ("An Opera for Flanders"). Knack (29 June 1983): 58-62.

Higson, Andrew. "Re-Presenting the National Past: Nostalgia and Pastiche in the Heritage Film." Fires Were Started: British Cinema and Thatcherism. 1993. Ed. Lester D. Friedman, Lester. London: Wallflower P, 2006. 91109.

Jacobs, Katrien, Kris Landuyt, Kris Lembrechts, and Georges Wildemeersch. Hugo Claus: Voor Twaalf Lezers en een Snurkende Recensent (Hugo Claus: For Twelve Readers and a Snoring Critic). Rijswijk: Elmar, 2004.

Lambert, Véronique. "De Guldensporenslag van Fait-Divers tot Ankerpunt van de Vlaamse Identiteit (1302-1838): De Natievormende Functionaliteit van Historio-Grafische Mythen" ("The Battle of the Spurs from Fait Divers to Milestone of the Flemish Identity (1302-1338): The Nation-Building Functionality of Historiographical Myths"). Bijdragen en Mededelingen betreffende de Geschiedenis der Nederlanden 115.3 (2000): 365-91.

Morelli, Anne, ed. De Grote Mythen uit de Geschiedenis van België, Vlaanderen en Wallonië (The Big Myths from the History of Belgium, Flanders and Wallonia). Berchem: EPO, 1996.

Naremore, James, ed. Film Adaptation. London: Athlone P, 2000. 
Nora, Pierre. Realms of Memory: The Construction of the French Past. 1984. Trans. Arthur Goldhammer. New York: Columbia UP, 1998.

Rosenstone, Robert A. Visions of the Past: The Challenge of Film to Our Idea of History. Cambridge: Harvard UP, 1995.

Temmerman, Jan. "Hugo Claus en de Vreugde van Vlaanderen" ("Hugo Claus and the Joy of Flanders"). De Morgen (6 June 1983): 8.

Tollebeek, Jo. "De Cultus van 1302: Twee Eeuwen Herinneringen" ("The Cult of 1302: Two Centuries of Memories"). 1302: Feiten en Mythen van de Guldensporenslag. Ed. Raoul van Caenegem. Antwerpen: Mercatorfonds, 2002. 194-239.

Tollebeek, Jo, and Tom Verschaffel. "Helden en Herdenkers. De Geschiedenis van een Romantische Mythe en een Nationaal Symbool" ("Hero's and Rethinkers. The History of a Romantic Myth and a National Symbol"). Omtrent 1302. Ed. Paul Trio, Dirk Heirbaut, and Dirk van den Auweele. Leuven: Leuven UP, 2002. $183-205$.

Trappeniers, Lieve. "De Leeuw Heeft voor het Eerst Gebruld" ("The Lion Has Roared for the First Time"). Het Laatste Nieuws (29 January 1984): 3.

Van den Bulck, Hilde. "Public Service Television and National Identity as a Project of Modernity: The Example of Flemish Television." Media, Culture \& Society 23.1 (2001): 53-69.

Verschooten, Gilbert. Hugo Claus. Brussels: Fantasy Film, 1986.

Wauters, Karel. "Literair-Historisch Essay over De Leeuw van Vlaanderen" ("Literary-Historical Essay on The Lion of Flanders"). De Leeuw van Vlaanderen of de Slag der Gulden Sporen: Tekstkritische Editie. Ed. Hendrik Conscience, Edward Vanhoutte, and Karel Wauters. Tielt: Lannoo, 2002. 395-410.

Willems, Gertjan. "Film Policy, National Identity and Period Adaptations in Flanders during the 1970s and 1980s." Historical Journal of Film, Radio and Television 34.4 (2014): Forthcoming.

Witte, Els. "Increasing Tension between the Communities and the Creation of a Federalised Belgium." Political History of Belgium: From 1830 Onwards. Ed. Els Witte, Jan Craeybeckx, and Alain Meynen. Brussels: ASP, 2009. 361-92.

Author's profile: Gertjan Willems conducts research in media and cinema studies funded by the Research Foundation of Flanders at Ghent University. Willems's recent publications include the book chapters The Producer and Belgian Cinema(s): The Case of Jean (and Jan) Van Raemdonck (Ed. Andrew Spicer, Anthony McKenna, and Christopher Meir, 2014) and, with Kevin Smets, Film Policy and the Emergence of the Cross-cultural: Exploring Crossover Cinema in Flanders (Belgium) (Ed. Sukhmani Khorana, 2013). E-mail: <gertjan.willems@ugent.be> 